\title{
Yerli Turistlerin Kendilerini Yabancılarla Karşılaştırması ve Hissettikleri Ayrışma
}

Local Tourists' Self-Comparison with Foreign Tourists and Feeling of Segregation

\author{
Gürkan AYBEK*, Altan DEMIREL**, Cansu Ece ÖNER*** \\ *(Sorumlu Yazar) Araştırma Görevlisi, Pınarbaşı Mah. Akdeniz Üniversitesi, Merkez Kampüsü Turizm Fakültesi Kat:1 Oda No:1-D-12A, 07058, Konyaaltı / Antalya. \\ E-Posta: gurkanaybek@akdeniz.edu.tr \\ ORCID: 0000-0002-5536-5440 \\ ** Öğretim Görevlisi, AKEV Üniversitesi, Meslek Yüksekokulu, Kadriye Mah. Celal Bayar Cad. No:5-6, 07525, Serik/Antalya. \\ E-Posta: altan.demirel@akev.edu.tr \\ ORCID: 0000-0002-1010-4116 \\ *** Yüksek Lisans Öğrencisi, Akdeniz Üniversitesi, Sosyal Bilimler Enstitüsü, Akdeniz Üniversitesi Enstitüleri Binası B Blok 2. Kat Dumlupınar Bulvarı Kampus, \\ 07058, Antalya. \\ E-Posta: eceoner95@gmail.com \\ ORCID: 0000-0002-9034-6050
}

MAKALE BILGILERI

Makale işlem bilgileri:

Gönderilme tarihi: 8 Ekim 2021

Birinci düzeltme: 12 Aralık 2021

Kabul: 11 Ocak 2022

Anahtar sözcükler: Yerli turist, Ayrışma, Netnografi, Sosyal karşılaştırma, Napolyon kompleksi.

\section{ARTICLE INFO}

Article history:

Submitted: 8 October 2021

Resubmitted: 12 December 2021

Accepted: 11 January 2022

Key words: Local tourist, Segregation, Nethnography, Social comparison, Napoleon complex.

\section{ÖZ}

Çalışmada yerli turistlerin yabancı turistler ile kendilerini nasıl karşılaştırdıklarını ve hangi temalar açısından ayrışma hissettiklerini ortaya koymak amaçlanmıștır. İkincil olarak, bu ayrıșma hissinin tetikleyici nedenlerine yönelik çıkarımlar yapılmıştır. Kuramsal altyapı, konu açısından uyumlulukları nedeniyle, sosyal karşılaştırma paradigması ve üstünlük-aşağılık ikilemi ile Napolyon kompleksi üzerine kurulmuştur. Netnografi yöntemi kullanılan çalıșmada veriler TripAdvisor online platformu üzerinden 28 Ağustos-14 Eylül 2021 tarihleri arasında toplanmıştır. Bulgular, tüketici temelli (işletmelerin hedef kitle tercihi, fiyatlandırma, kalite belirleyiciliği, hizmet alma) ve sosyolojik temelli (genel davranış ve tutum, kültürel ve tarihi değerlere verilen önem, çevre duyarlılığı) olarak iki ana tema altında değerlendirilmiştir. Ayrışma hissini ve potansiyel yerli turist kompleksini yaratan dört ana aktör; yerli esnaf/işletmeler, çalışanlar, yabancı turistler ve diğer yerli turistler olarak sıralanmaktadır. Yerli turistler özellikle tüketici temelli ayrışma temalarında ikinci plana atılmış ve haksızlığa uğramış hissetmektedir. Bazı yerli turistlerin yorumlarından bu hislerin etkisi ile adeta öç almaya yönelik tutumların gelişebileceği de anlaşılmaktadır. Ancak kimi yerli turistler bizzat diğer yerli turistleri de -özellikle beklenti yönünden- eleştirmektedir.

\section{GiRiş}

Türkiye'de özellikle batı ve güney bölgeleri k1yı şeritleri için önemli bir kalkınma faktörü olan turizm sektörü (Seckelmann 2002), çoğunluk- la yabancı turistlere yönelik bir yapıya sahiptir (Şanlığlu ve Özcan 2017). Sektörün yabanc1 turist merkezli olmasının arkasında özellikle döviz getirisi unsurunun yattığ ${ }_{1}$ düşünülebilir 
(Bozkurt ve Pekmezci 2015; Şanlığlu ve Özcan 2017). Kültür ve Turizm Bakanlığ1 (2021), gelen yabancı turist sayısinın 2018 yılında 40 milyon ve 2019 yılında 45 milyon civarında olduğunu ifade etmektedir. Bu veriler de bunu doğrular niteliktedir. Ancak bir destinasyon, benzer ilgi ve motivasyonlara sahip şekilde hareket eden yerli turistlerce de ziyaret edilmektedir (Güzel 2011). Yerli ve yabancı turistlerin ayn destinasyonda karşılaşması sırasında, neredeyse her dönemde yerli turistlerin göreceli olarak ikinci plana atıldığı yönünde kaygılar bulunmaktadır (Kuşluvan 2002; Yenişehirlioğlu ve Salha 2020). İkinci plana atılmış olma hissi ise beraberinde yerli ve yabancılara yönelik bir ayrışma olduğu fikrini getirmektedir (Dönmez ve Çakıcı 2013a; 2013b).

Alanyazın incelendiğinde yerli turistler, yabancı turistlerin genel davranış ve görgü kuralları yönünden kendilerinden farklı olduklarını hissetmekte (Dönmez ve Çakıcı 2013a), ödenen ücret ve alınan hizmet kalitesi yönünden bir adaletsizlik algılamaktadır (Dönmez ve Çakıcı 2013b; Yenişehirlioğlu ve Salha 2020). Ancak yerli turistin yabancı turist karşısında kendisini nasıl konumlandırdığı ve karşılaştırdığı belirgin şekilde ortaya koyulmamıştır. Söz konusu unsurların belirginleştirilmesi, turizm paydaşlarının yerli turistlerin gözünden sektördeki sorunları tespit edebilmeleri yönünden gereklidir. Çünkü yerli turistler, özellikle salgın ve siyasi istikrarsızlık benzeri kriz dönemlerinde turizm açısından önemli hale gelmektedir (Şahin vd. 2018). Seyahat işletmecilerinin, iç pazarın "turizmin sigortası" olduğu yönündeki görüşleri de bununla paraleldir (Coşan 2021). Nitekim çalışmanın ilk amacı olan yerli turistlerin, yabancı turistlerle aralarında hissettikleri ayrışma faktörlerinin belirlenmesi ve hangi yönlerden üstün/avantajl1-aşağ1/dezavantajlı hissettiklerinin ortaya konması da bu doğrultuda şekillenmiştir.

Türkiye Cumhuriyeti'nde de 2016 yılında artan terör olayları ve 2020 'den bu yana yaşanan pandemi sebebiyle ülkeler arası seyahat kısıtlamaları ve insanların algıladıkları risk düzeyinin artmasıyla Türkiye Cumhuriyeti'ne gelen yabancı turist sayısında azalma yaşanmış ve yerli turistlerin turizmin bu açığını kapatacağına yönelik bir inanç gelişmiştir (Köşker 2017; Yenişehirlioğlu ve Salha 2020). Fakat olağan dönemlerde özellikle yerli esnafın ve işletmelerin hedef pazar olarak yabanc1 turisti tercih etmesi (Sar1 ve Bayraktar 2018) sonucu yerli turistlerin neredeyse turistik deneyimin her anında ikinci plana atılmış hissetmesi (Yenişehirlioğlu ve Salha 2020), kriz dönemlerinde turizme katılma konusunda hevesli olmamalarına neden olabilir durmaktadır. Buradan hareketle, hissedilen ayrışma karşısında gelecekte ortaya çıkabilecek potansiyel tutum ve davranışların açıklanması da araştırmanın ikinci odağıdır.

Araştırmanın bölgedeki turizm paydaşlarının, yerli turistin gözlerindeki konumlarını ve hangi yönlerden kendilerini geliştirmeleri ve önlem almaları gerektiğini açıklığa kavuşturacağına inanılmaktadır. Ayrışma faktörlerinin somutlaştırılması bu bağlamda kolaylaştırıcı olacaktır. Alanyazında bu konu özelinde yapılmış çalışma olmaması ve yakın konulara odaklanan araştırmaların kısıtlılığı (örn. Dönmez ve Çakıcı 2013a; 2013b), araştırmanın alandaki bir boşluğu doldururken gelecekteki çalışmalar için yol gösterici olmasını sağlamaktadır. Öte yandan bu k1sıtlılık, çalışmanın amaçlarına ulaşmak için kavramsal çerçeve altında yer alan turizm dışındaki alanların kuramlarından yararlanmayı zorunlu kılmıştır.

\section{KAVRAMSAL ÇERÇEVE}

Yerli turistler ve yabancı turistler, benzer deneyimleri yaşamak için aynı destinasyonda karşılaşan ancak farklı muamele gören veya olaylara farklı tepki veren iki ayrı grup olarak nitelendirilebilmektedir. Öyleyse yerli turist perspektifinden yabancı turistlerin karşı grup olarak görülmesi olasıdır. Bu perspektifi açıklamak adına sosyal psikoloji ve bireysel psikoloji alanından kuramlara başvurulması uygun görülmüştür.

\section{Sosyal Karşılaştırma Paradigması}

Sosyal karşılaştırma paradigması, sosyal kimlik kuramının önermelerinden biri olarak, bireyin dahil olduğu iç grup ve bağlı olmadığ 1 diş grup arasındaki karşılaştırmalarını "biz ve diğerleri" 
ayrımına dayanarak yaptığını öne sürmektedir (Turner, 1975; Loy 2017). Teoriye göre birey için kendini tanımlamaya uygun gördüğü niteliklere sahip sosyal bir grubun kimliğini karşılaştırma ve uyumlama sonucu benimsemesi ve içselleştirmesi mümkündür (Trepte ve Loy 2017). Ancak bu benimseme ve içselleştirme beraberinde "biz" olarak tanımlanan iç grubun, "onlar" olan dış grupla karşılaştırılmasına yol açacaktır (Turner 1975). Söz konusu karşılaştırma iç grubu daha ahlaklı, doğru, kabul edilebilir ve güçlü görürken; dış grubu zayıflık, genel ahlak ve görgüden uzak olmak ve güçsüzlük gibi olumsuz niteliklere sahip olmakla bağdaştırmaya kadar gidebilmektedir. Bir açıdan düşünüldüğünde bireyin ait olduğu grubu daha üstün görmesi, Adler'in bireysel psikoloji kuramındaki üstünlük kompleksinin gelişmesini sağlayan sosyal etkileşim ortamını yaratabilmektedir (Selvi 2018).

\section{Napolyon Kompleksi ve Üstünlük-Aşağılık İkilemi}

Bireysel psikoloji kuramına göre, birey kendini diğer bireylerden üstün görmeye yatkınken, sosyal karşılaştırma paradigmasında birey, ait olduğu grubu diş gruptan üstün görme eğilimindedir. Bu bağlamda bireysel psikoloji kuramı ve sosyal karşılaştırma paradigmasının birbiriyle örtüştügüunü söylemek mümkündür. Her ne kadar alanyazındaki temel varsayım bireyin kendini veya ait olduğu grubu diğerinden üstün gördüğü yönünde olsa da özellikle bireysel psikoloji kuramında üstünlük kompleksinin geri planında az veya çok şekilde kendini gösteren bir aşağılık kompleksi olduğu öne sürülmektedir (Bayram 2018; Selvi 2018). Bireyin diğerlerine karşı güçsüz veya eksik hissettiği yönlerini kapatmak adına kendini üstün görmeye yatkın olduğu düşünülmektedir. Buna ek olarak eksikliklerle baş etmek adına bir diğer savunma mekanizması olan $\mathrm{Na}$ polyon Kompleksi de bu noktada ele alınmalıdır. Kısa boylu erkeklerin kavga etmeye daha yatkın olması metaforuyla tanımlanan bu kompleks, bireyin eksik gördüğü yönlerini kapatmak ad1na daha girişken olması ve daha sık agresifliğe başvurması olarak açıklanmaktadır (Knapen vd. 2018).

\section{Yerli Turistlerin İlgili Kuramsal Altyapıya Göre Değerlendirilmesi}

Yerli turistler, yabancı turistlere karşı genel bir biz ve onlar ayrımı yapmaktadır (Dönmez ve Çakıcı 2013a). Bahsi geçen kuramlar, yerli turistlerin ait oldukları "yerli turistler" iç grubunu "yabancı turistler" dış grubuyla nasıl karşılaştırdıklarını anlamak için uygun teorik altyapıyı sağlamaktadır. Bu bağlamda bu çalışmanın ana amacı yerli turistin, yabancı turisti kendine göre ve kendini yabancı turiste göre nasıl konumlandırdı ğını ve hangi temalar altında ayrışma hissettiğini anlamaktır. Bu konumlandırmanın anlaşılabilir kılınmasını sağlamaya yönelik olarak, temeli bireyin belirli bir gruba aidiyeti ve diğer gruplarla ayrımına dayanan sosyal kimlik kuramının sosyal karşılaştırma paradigmasından yararlanılmıştır. Bu sosyal karşılaştırma içerisinde, yerli turistlerin hangi yönlerden üstünlük-eksiklik hissettikleri, bireysel psikolojinin bir uzantısı olan Napolyon Kompleksine dayalı olarak incelenmiştir. Böylelikle yerli turistlerin, yabancı turistlere karşı içerisine girdikleri üstünlük-aşağ1lık ikileminin arkasında yatan potansiyel bir yerli turist kompleksi olup olmadığına dair ve var ise ana nedenlerinin neler olduğuna dair çıkarımlar yapılabilmesi de mümkün olacaktır.

\section{YÖNTEM}

Araştırmanın deseni, toplulukların davranışlarını daha iyi anlamak ve veri toplamak için sanal ortamda sunduğu imkanlar nedeniyle (Kozinets 2010), çalışmanın temel mantığına uygun görülerek netnografi olarak belirlenmiştir. Bunun nedeni hem yorum çeşitliliği açısından farklı perspektifler sunması hem de yorumu yapan turistlerin bir araştırmacının yönlendirmesi altında kalmadan ve üzerinden çok zaman geçmeden deneyime dair düşündüklerini paylaşabilmesidir. Yerli turistlerin ortak motivasyon ve kaygılarını yorumlarda yansitıyor oluşu, netnografik yaklaşımin ele alması gereken sanal topluluk gerekliliklerini karşılamaktadır.

Öncelikle araştırmanın amacına hizmet edecek verilerin bulunduğu internet platformuna karar verilmiştir. Çalışmanın turizm alanında yapılmasından kaynaklı TripAdvisor tercih edilmiştir. 
Söz konusu yorumlar herkesin erişimine açlk bir platformda yazıldığından ve kullanıcı, site tarafından sunulan şartları zaten kabul etmiş olduğundan ek bir izne gerek duyulmamıştır (Allen vd. 2006). Aynı zamanda TripAdvisor sitesi de verilerin telifsiz olduğu ve üçüncül kişilerce türev çalışmalarda kullanılabileceği yönünde bilgilendirme sağlamaktadır (TripAdvisor 2018).

Veriler "yabancı", "yabanci turist", "yerli", "yerli turist", "Türk", "biz", "bizim" ve "onlar" anahtar kelimelerinin Google üzerinden "site:tripadvisor. com" parametresiyle aranması sonucu toplanmıştır. Yorumlar seçilirken yönlendirici olmaması adına içeriğinin olumlu veya olumsuz olmasına bakılmamıs, puanlamalar dikkate alınmamıştır. Yorumların sadece yerli turistlerce yapılmış olmasına ve içeriğinin yerli ve yabancı turist karşılaştırması içermesine özen gösterilmiştir. Yorumlara yönelik ölçütler konması netnografik yaklaşım için topluluğun sınırlarını, nitel araştırma içinse nakledilebilirliği güçlendirmektedir (Kozinets 2010; Meriam 2015).

Konuyla ilgili yapılmış tüm yorumlara erişilmek istendiği için zaman sınırlaması uygulanmamış, veriler 28 Ağustos-14 Eylül 2021 tarihleri arasında toplanmıştır. Süreç sonunda analize uygun 76 yorum belirlenmiş, içerdikleri anlam bozulmadan yazım kurallarına uyacak şekilde düzenlenmiş ve değerlendirilecek kısımlara göre seyreltilerek içerik analizine başlanmıştır. Araştırmanın amaçlarına yorumlarda yer alan kelime, örüntü ve temaların açığa çıkarılmasıyla ulaşılabileceği için içerik analizi tercih edilmiştir (Meriam 2015). Bir lokasyon sinırlaması olmamasına rağmen yorumların önemli bir bölümünün (yaklaşı \%95'i) Türkiye' nin güney-batı kıyıları olan Antalya ve çevre ilçelerde yaşanan turistik deneyimlere ilişkin yapıldığı belirtilmelidir.

İçerik analizi sürecinde, yazarlar kodlanmış ifadeleri bağımsız olarak temalandırmışlardır. Ardından bir araya gelerek temalar üzerinde hemfikir olmuşlardır. Süreç neticesinde bir kod şeması oluşturulmuştur. Konu üzerine oturmuş bir alanyazın olmadığından oluşturulan temaların ve ifadelerin uyumunu değerlendirmek için oluşturulan kod şeması, turizm alanında çalışan dört uzmana gönderilmiş ve değerlendirmeleri istenmiştir. Uzman görüşleri sonucunda belirle- nen temaların ve maddelerin uyumlu olduğu kanısına varılmıştır. Araştırmayla ilgili uzman grubu haricindeki iki farklı akademisyenin ayrıca görüşü alınmıştır. Farklı bakış açılarının araştırmaya dahil edilmesiyle nitel araştırmanın inandırıcılığ1 ve güvenilirliği yönünden metodolojik anlamda bir üçgenleme sağlandığ 1 söylenebilmektedir (Meriam 2015). Ek olarak, güvenilirliğin sağlanması için bulgular bölümünde belirlenen temalar tanımlanmış ve yorumlardan örneklerle alıntılar sunulmuştur.

\section{BULGULAR}

İlk olarak yerli turistler ve yabancı turistler arasındaki ayrışma hissinin düzeyine değinmek gerekmektedir. Yorumlar incelendiğinde yerli turistlerin yabancı turistlere göre geri plana atılmış ve ayrımcılığa uğramış hissettiği doğrulanmaktadır;

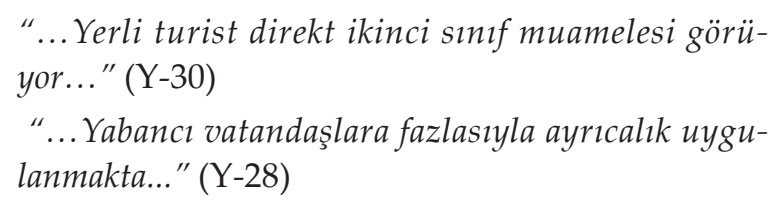
lanmakta..." (Y-28)

Buna ek olarak, kimi yerli turistler turist tanımını yabancı turistlerle bağdaştırmakta ve yabancı turist söylemi yerine doğrudan turist demeyi tercih etmektedir;

“...Tüm otel yabancılara göre tasarlanmış... ...Türk olmanıza rağmen turist muamelesi görüyorsunuz..." (Y-64)

“...Bir Türk olmanıza rağmen oraya girdiğiniz anda turist muamelesi başlıyor..." (Y-76)

Tüm bu yorumlar özelinde değerlendirildiğinde, yerli turistler ve yabancı turistlerin gerçekten de iki ayrı sosyal grup olarak ele alınabileceği anlaşılmaktadır. Yerli turistler belirgin şekilde yabancı turistlerle sosyal karşılaştırma içerisine girmiş ve biz ve onlar şeklinde ayrışmış hissetmektedirler. Bu ayrışmanın hangi temalar altında geliştiği Tablo 1'de sunulmuştur.

\section{Işletmelerin Hedef Kitle Tercihi}

İşletmelerin turistik deneyim esnasında ürünhizmet satışı aşamasında alışveriş için öncelikle yabancı turistleri tercih ettiği, yerli turistleri ise 
Gürkan Aybek - Altan Demirel - Cansu Ece Öner

Tablo 1. Yerli Turistlerin Yabancı Turistlerle Aralarında Hissettikleri Ayrışmanın Boyutları

\begin{tabular}{|c|c|c|c|}
\hline Tema & Alt Tema & Tanım & Yorum Sayısı \\
\hline \multirow{4}{*}{$\begin{array}{l}\text { Tüketici } \\
\text { Temelli } \\
\text { Ayrışma }\end{array}$} & İşletmelerin Hedef Kitle Tercihi & $\begin{array}{l}\text { İşletmelerin ürün satışı ve müşteri } \\
\text { çekme faaliyetleri sırasında hissedilen } \\
\text { ayrışma }\end{array}$ & 11 \\
\hline & Fiyatlandırma & $\begin{array}{l}\text { Fiyatlandırma politikaları açısından } \\
\text { hissedilen ayrışma }\end{array}$ & 14 \\
\hline & Kalite Belirleyiciliği & $\begin{array}{l}\text { Turistik hizmet ve ürün kalitesinin } \\
\text { belirlenmesi ve erişilmesi açısından } \\
\text { hissedilen ayrışma }\end{array}$ & 10 \\
\hline & Hizmet Alma & $\begin{array}{l}\text { Hizmet alma sırasında hizmet kalitesine } \\
\text { yönelik hissedilen ayrışma }\end{array}$ & 16 \\
\hline \multirow{3}{*}{$\begin{array}{l}\text { Sosyokültürel } \\
\text { Ayrışma }\end{array}$} & Genel Davranış ve Tutum & $\begin{array}{l}\text { Genel davranış kalıpları ve görgü } \\
\text { kurallarıyla tutumlar açısından } \\
\text { hissedilen ayrışma }\end{array}$ & 19 \\
\hline & $\begin{array}{l}\text { Kültürel/Tarihi Değerlere Verilen } \\
\text { Önem }\end{array}$ & $\begin{array}{l}\text { Kültürel ve tarihi turistik değerlere } \\
\text { atfedilen önem açısından hissedilen } \\
\text { ayrışma }\end{array}$ & 4 \\
\hline & Çevre Duyarlılığı & $\begin{array}{l}\text { Çevreye karşı duyarlı olma açısından } \\
\text { hissedilen ayrışma }\end{array}$ & 2 \\
\hline
\end{tabular}

fazla dikkate almadıkları yerli turistlerce açıkça fark edilmektedir;

“...çok sayıda hediyelik eşya satış dükkanları mevcut. Fakat daha çok yabancı turiste satış yapmaya çalışıyorlar. Neden acaba?!..." (Y-1)

“...Yerli turist gördüklerinde kısa cevaplarla geçiştirmelerini turist cenneti bir mekânın esnafina yakıştıramadım." (Y-75)

Öyle ki bu ayrım müşteri olarak yerli ve yabancıya sunulan ürünlerin çeşitliliğine ve hatta alışveriş için belirlenen para birimine kadar etkisini göstermektedir;

“...Menü daha çok yabancı turistlere yönelik öyle ki yerli turist için daha az seçeneğe sahip ayru bir menü daha bulunuyor..." (Y-37)

“...alışveriş dükkanları etiket olayında sadece Euro kullanıyor Türk parası yazmıyor..." (Y-2) (Y-76)

Alanyazında da özellikle yabancı turistlerin esnafın yoğun ilgisiyle yerli turistlere göre daha çok karşılaştı̆̆ 1 dillendirilmektedir (Dönmez ve Çakıcı 2013b; Üngüren vd. 2015). Bunun ne- deninin destinasyonda yer alan işletme sahiplerinin ve esnafın yerli turistle alışveriş yapmaktansa daha yüksek harcamalar yapabilme kabiliyetine istinaden yabancı turistle alışveriş yapmayı tercih etmesi olduğu söylenebilir (Sarı ve Bayraktar 2018). İşletmelerin hedef kitle olarak yabancıları öncelikli görmesi içselleştirilmiş durumdadır. Öyle ki zaman zaman yabancı yerine yerli turistin tercih edilmesi bile memnuniyeti arttırabilmektedir;

“...Gittiğimizde tüm masalar doluydu ve çalışan arkadaşlar hemen yardımcı oldu. Hatta bize beklettiği masaya bir yabancı turist oturmak istedi ve bizim sırada olduğumuzu ifade etti. Bu yorumu şu yüzden özellikle yazdım. Malum turizm de yabancı turist ve yerli turist ayrımı artık çok üzgün olarak ülkemizde artiyor..." (Y-44)

Bunun yanı sıra yerli turistin dış görünüş olarak yabancı turiste benzemesi dahi hedef kitle tercihi açısından bir karışıklık oluşmasına ve yerli esnafın iletişim kurma çabasına yol açmaktadır;

"...Esnafin her sarışını yabancı turist sanıp "Hello" demesi biraz komik dursa da görülmeye değger." (Y-3) 
“...Giyinişimizden ve tipimizden yabancı zannedildik ve potansiyel müşteriymişiz gibi bakışlara maruz kal$d \imath k \ldots "(\mathrm{Y}-76)$

Yaşanan küresel pandemiyle yabancı turistin yokluğu, işletmeleri hedef kitle olarak yerli turisti seçmek zorunda bırakmış ve bu durum yerli turistlerce olumlu algılanmıştır;

“... Yabanci turist olmadiğından herhalde Antalya esnafinda çok olumlu gelişmeler var, yerli turiste karşı..." (Y-73)

\section{Fiyatlandırma}

Yerli turistlerin turistik faaliyetlerde fiyatlandirma açısından hassas oldukları alanyazında ortaya konmuştur (Ayaz ve Musellim 2021). Bu hassasiyete ek olarak fiyat açısından ayrışma olduğu düşüncesinin de var olduğu görülmüştür (Dönmez ve Çakıcı 2013b);

“...ücret bilgisi almak için telefon açtığımda yabancı mı Türk mü olduğumu sordular... Bence çok yanlış..." (Y-8)

"...her yerde "yerli mi yabancı mi?" diye soruyorlar. Bu çok kabaca bir tarife..." (Y-9)

Kimi yorumlarda bu adaletsizlik bir empatiyle değerlendirilmektedir;

“...bizlere ayrr yabancı turistlere ayr fiyat politikası uygulanıyor sanırm, ülkemizi tercih eden insanlara hiçbir şekilde mağduriyet yaratmamalıyız..." (Y-7)

Yine de yorumların büyük çoğunluğu yerli turistlerin bu fiyat adaletsizliğinden olumsuz etkilenen taraf olduğunu öne sürmektedir;

“...Niye yerli turiste pahal da yabanct turiste ucuz?..." (Y-34)

"...Yabancr turistlere daha ucuz, kendi ülkesinde kendi insanina daha pahal fiyat belirleyip hizmette ise tam tersini yapan bu otele gitmeyi düşünenler tekrar düşünün derim..." (Y-53)

Ürün ve hizmetlerin fiyatları yerli turist için yüksekken yabancıların rahat satın alabilmesi, fiyat düzeyinin yabanciya göre belirlenmesine ve hizmet alma esnasında bunu avantaja çevirmelerine neden olmaktadır;
"Çok güzel tesis yapılmış fakat sadece yabancı turistler için sanırım... ....çok pahalı..." (Y-10)

“... ödediğimiz paranın içinde, kapıdaki valeden restorandaki garsona kadar hepsine verilebilecek bahşişi de içeren meblă̆ bulunurken ecnebiler daha ucuza geldiklerinden bunu (bahşiş olarak) veriyor..." (Y-59)

“...Mekân güzel esnaf paragöz. Turist tarifesi almış yürümüş." (Y-74)

Döviz kuru, bu temadaki ayrışmanın ana nedeni olarak nitelendirilmektedir. Gerçekten de kurdaki artış, Türk lirasının ödeme kabiliyetini düşürmektedir. Özellikle kur artışının yol açtığ 1 fiyat farkları, yabancı turistin harcama kapasitesini arttırırken yerli turisti kisitlamaktadır (Bozkurt ve Pekmezci 2015);

“...Doların iki katına çıkması ile otel fiyatları da iki katına çıkmış durumda. Yabancı turistler için değişen bir şey olmadı ancak yerli turist için fiyatlar iki katına çıkmış durumda..." (Y-62)

Yabancı turistlerin, yerli turistin gözünde harcayacakları parayı belirleyen taraf olma özelliğine ek olarak, alınan ürün veya hizmetin kalitesi de yabancı turiste bağlı görülmektedir.

\section{Kalite Belirleyiciliği}

Bir turizm bölgesindeki tesis, ürün ve hizmet kalitesi, o bölgeyi ziyaret eden turistlere göre belirlenmektedir (Kılıçaslan ve Aydınözü 2000; Çakar 2018). Bu belirleyicilik rolünü ise çoğunlukla yabancı turistler üstlenmektedir (Dönmez ve Çakıcı 2013b). Bu çalışmanın bulguları da bunu doğrular niteliktedir;

"Ĕger yabancı turist azınlıktaysa o otele hiç yanaşmayacaksin. Çünkü gördüğün hizmet ve hizmet kalitesi onlara bağll..." (Y-35)

"Yabancı turistler gittikten sonra yiyecek kalitesi düşüyor..." (Y-50)

Hatta bir destinasyonun veya destinasyonda yer alan işletmelerin tercih edilmesinde ve başkalarına önerilmesinde yabancı turistlerin orayı tercih etmesi rol oynamaktadır;

“...kesinlikle tavsiye ederim. Yerli turist neredeyse yok, çoğunluk Alman turist..." (Y-72) 
“...müşterilerinin büyük kısmının yaşını almış yabancı turist olması nedeniyle sakin olan bir yer oluşu dikkate alındiğında tercih edilebilecek bir yer." (Y-22)

Yapılan yorumların bir kismında, yerli turist ve yabancı turist ayrışmasının işletme tarafından açıkça hissettirildiği ve bu durumun yerli turistte tepkiye yol açtığı görülmektedir;

“...(iyi kalitede ürünler) ikram ediyorlar ama yabancı turist varken yapılan firma anlaşmaları olduğu için bu ürünler vardı. Belki seneye olmaz. Çünkü yabancı turist yok eskisi gibi..." (Y-36)

"...yemekler berbat, aynı şeyleri tekrar tekrar veriyorlar. "Bu yıl yabancı turist yok ondan böyle" dediler, oysa biz onlardan çok para veriyoruz, o zaman almayın otele..." (Y-65)

Ancak yabancı turist, bazı tatilciler tarafından yüksek kaliteyle değil, yerli turistin düşük kaliteye mecbur bırakılmasıyla bağdaştırılmaktadır;

“...Iranl aileleri görüyoruz, tur teknelerinin o gürültülü müziklerine bakmadan coşkuya katılıyorlar. Müzik o kadar yüksek ki biz maalesef tekne turuna katılamıyoruz..." (Y-6)

“...domatesi tekrar yıkamaktan kimsenin eli aşınmaz. Yabancs turist ne verirsek yiyor deyip, yerli turistin makul taleplerini geçiștiremezsiniz..." (Y-60)

“...Yemekler Türkler için vasat ama yabancı turistlere ve turlara hitap ettiği için onlara iyi olabilir..." $(\mathrm{Y}-69)$

"...Çay istediğimizi de ilettik ve aldı̆̆ımı cevap çoook enteresandi. Çay yok. Nasıl yani menüde var ve 2,5 TL dediğimde ise "yabancı turist çay içmiyor, yerliye de akşam çay vermiyoruz" dedi..." (Y-70)

Sonuç olarak, alınacak ve beklenen hizmetin kalitesinde belirleyici olan tarafın yabancı turist olması, yerli turist açısından bir memnuniyetsizlik yaratabilmektedir.

\section{Hizmet Alma}

Yerli turistlerin yabancı turistlerle aralarında hissettikleri ayrışma hizmet alma esnasında yoğun şekilde artmaktadır. Yerli turistler, hizmet alırken yabancı turistlere kendilerinden daha fazla ilgi gösterilmesinden rahatsız olmaktadır;
“...Türk müşterilere değer vermiyorlar..." (Y-25)

"...garsonlarm hemen hemen hepsi yabanci turistlerle daha ilgililer. Yerli turistlerin önemsenmemesi kendimizi kötü hissetmemize neden oldu..." (Y-33)

“...Servis personeli adam seçiyor. Türk iseniz kesinlikle sıfır ilgi alaka. Yabancı misafirseniz çayınıza kadar servisiniz yapultyor..." (Y-67)

Hatta hizmet alma esnasında hissedilen bu ayrım, yaşanan deneyim olumlu olsa dahi kendini göstermektedir;

“...personel ilgide gayet başarnl fakat yabancı turiste olan ilgi kat ve kat daha fazla..." (Y-19)

“...otel mükemmel bence her şeyi güzel lakin personelin yabancı turiste hep güler yüzlü davranıp hizmet yapması. Bizim yüzümüze bile bakmaması garip geldi. İnanılmaz bir yerli turist ayrımı var..." (Y-24)

Hem hizmet alma hem de diğer tüketici temelli ayrışma boyutlarında yaşanan olumsuz deneyimler, beraberinde yerli turistler arasında adeta intikam almaya yönelik bir tutum gelişmesine yol açmış görünmektedir;

"...eninde sonunda hepiniz yerli turistin cebine bakacaksinız..." (Y-32)

“...kendi halkın her zaman burada, onlara müşteri olarak her zaman muhtaçsınız..." (Y-36)

Alanyazındaki genel kabul de yerli turistin yabancı turist karşısında haksızlığa uğramış hissine sahip olduğudur (Dönmez ve Çakıcı 2013b; Yenişehirlioğlu ve Salha 2020). Ancak araştırma kapsamında ele alınan veriler, azınlık da olsa bazı yerli turistlerin yerli ve yabancı turiste eşit davranıldığını ve beklentilerin daha doğru belirlenmesi gerektiğini düşündüğünü işaret etmektedir;

“...yabancı turist sayısı fazla olmasına karşı, personel Türklere çok yardımsever ve güler yüzlü ve işini bilinçli yapıyor..." (Y-63)

"...otelin \%80 yabancı turist olduğunu var sayarsak sizlerle ilgilenilme oranı ne kadar fazla olabilir buradan pay biçmek lazım..." (Y-66)

“...tatilden ne beklediğinize bağlı... ...Çalışanlar işini yapıyordu, alt tarafi bir tatil yapıyorum ve çalışanlarm bana lord gibi davranmasinı beklemiyorum..." (Y-61) 


\section{Genel Davranış ve Tutum}

Bazı yerli turistler, tüketici temelli ayrışma boyutlarından ayrı olarak, sosyal anlamda da kendilerini yabancı turistlerle karşılaştırmaktadır. Dönmez ve Çakıcı (2013a), yerli turistlerin yabancı turistlere karşı bazı sosyal bağlamlarda üstün bazılarında ise daha geride hissettiğini ortaya koymuşlardır. Bu çalışmanın bulguları da ilgili araştırmacıları desteklemektedir. Genel davranış ve tutum açısından özellikle olumsuz yorumların çoğunlukta olduğu söylenebilir;

“...Soyunma kabinleri iğrenç kokuyor. Büyük ihtimalle uzak olan tuvalete gitmeye üşenenler soyunma kabinlerine yapmış! Çok fazla yabancı var, büyük ihtimalle onlar yapmıştır. Türklerden böyle bir iğrençlik beklemiyorum çünkü..." (Y-12)

"Her yer kıl, çöp. Havuz ile alakası olmayan full makyajlı yabancı kızlar. Ellerinde içki olan insanlar vardi..." (Y-15)

“...otelde konaklayan yabancı turistler konakladı̆̆ım diğer otellere nazaran daha elit insanlardı ve öyle içip taşkınlık yapan turistlere benzemiyorlardı." (Y-29)

Ancak yine de tüm yerli turistlerin yabancı turistleri olumsuz özelliklerle bağdaştırdığını söylemek doğru olmayacaktır. Birkaç yorum yabanc1 turistleri, yerli turistten daha uyumlu ve $11 \mathrm{ml}$ görmektedir;

"... Yabance turist Türk turistten daha kaprislidir, onlar sadece olay çıkmasın tatsızlik olmasın diye seslerini çıkartmazlar..." (Y-52)

“...birçok otele gittim turistler bizim yerlilerden daha ılımlılar açıkçası..." (Y-51)

Fakat kimi yerli turistler, aynı gruba dahil olmalarına rağmen, diğer yerli turistleri yabancı turistlere göre oldukça aşağ 1 bir düzeye koymaktadırlar;

“...Yerli turistler yabancı turistlere göre daha soğuk olmasindan sohbetler de daha kısa sürüyor... ...bu sebeple onlara daha sicak davranılıyor gibi gözüküyor ama alakası yok. Çuvaldızı kendimize batıralım biraz..." (Y-42)

"...bazı insanlarımız... ...maalesef tesisi pis, sayg1sızca kullanıyor. 2 bin TL ile oteli satın aldığını sa- nanlar var maalesef... ...Şu bir gerçek, yabancı turist daha saygill ve daha medeni..." (Y-45)

“...Türklerden hep şikâyet var... ...Şımarık ve kaprisli insanlar yüzünden her yerde Türkler huzur kaçıryor..." (Y-58)

\section{Kültürel/Tarihi Değerlere Verilen Önem}

Kültürel ve tarihi değerleri barındıran yerlerle ilgili yapılan araştırmaların bir kısmı yabancı turistlerin bu değerleri daha fazla talep ettiğini vurgularken (örn. Kızıldemir ve Sarışık 2018) bir kısmı ise yerli turistlerin kültürel motivasyonlara daha fazla sahip olduğunu belirtmektedir (örn. Altun ve Çınar 2019). Bu çalışma ilgili ikilemde bir taraf tutmamakla beraber yerli turistlerin, miras alanlarının kendilerine ait değerler olmasına rağmen, yabancı turistler tarafından daha fazla ilgi gördügünü belirttikleri sonucuna ulaşmıştır. Hatta iç gruba yönelik sürekli bir öz eleştiri yapma eğilimi olduğu dikkat çekmektedir;

“...Ne yazık ki yabancı turistlerin bir kere daha yerel turistlerden daha ilgili ve duyarlı olduğunu gördüm..." (Y-46)

"...her daim yabanci turist olan bir yer, biz daha ilgisiziz sanki daha çok önem verilmeli bence..." (Y-54)

"Her insanın gezip görmesi gereken bir müze......Daha çok yabancı turistlerin gezmesi ve yerli turistlerin az olması düşündürücü." (Y-71)

Yerli turist açısından kültürel bilinirliğin yüksek olması, yerel kültürel etkinlik adı altında sunulan eğlencelerin eskiyle karşılaştırıldığında cazibesini yitirmesine veya sıradanlaşmasına neden olabilmektedir (Soylu vd. 2018). Yerli turistlerin aksine yabancı turistler, bölgeye özgü eğlence unsurlarıyla karşılaşmaktan daha çok keyif almaktadırlar;

“...dans ve oryantal gösterileri yapılmakta, halk oyunları gösterisi sunulmaktadır. Ancak bu gösteriler daha çok yabancı turiste cazip gelmektedir. Yerli turist için halk oyunları ya da oryantal gösterisi eski cazibesinde değildir..." (Y-41)

\section{Çevresel Duyarlılık}

Çevresel duyarlılık, hem turistik çekiciliğin yaratılması ve sürdürülebilmesi (Kınacı vd. 2011) 
hem de doğa üzerinde turizm kaynaklı olumsuz etkilerin ortaya çıkmaması (Tang 2015) için önemli görülmektedir. Ancak yerli turistlere göre yabancı turistlerin çevreye duyarlılığı çok daha yüksektir;

“...yabancıların çok fazla ziyaret etmesinden dolayı da doğal olarak temiz kalabildiği için kendimi resmen Avrupa'da bir yerde sandım. Keşke halkımı da bu yabancilar kadar duyarlı olsa, elindeki çeri çöpü izmaritini yere firlatmasa..." (Y-5)

“...Yabancı turist hiç görmedim, yerli turistler de hunharca yemiş, içmiş, atmış çöplerini. Çöpler olmasa o kadar güzel ki..." (Y-20)

\section{TARTIŞMA VE SONUÇ}

Bu çalışma, öncelikli olarak yerli turistlerin yabancı turistlerle kendilerini hangi boyutlarda karşılaştırdıklarını ve ayrışmış hissettiklerini sosyal karşılaştırma paradigmasıyla; ikincil olarak üstünlük-aşağılık ikilemindeki konumlarını Napolyon Kompleksine atıfla incelemiştir. Ortada bir çeşit yerli turist kompleksi mi olduğu yoksa bu hislerin karşılaşılan ayrımcılığın doğal bir sonucu mu olduğu tartışılmıştır.

Araştırmanın alanyazına önemli katkılarından biri, yerli turistlerin öz karşılaştırmalarının ve hissettikleri ayrışmanın nedenlerinin ve boyutlarının kavramsallaştııılmasıdır. Kimi yerli turistler kendilerini turist olarak görmemektedirler. Bu durum biz ve onlar karşılaş̧ırmasının temelinde ülke vatandaşı Türkler ve dişarıdan gelen yabancılar benzeri bir altyapı olduğunu düşündürse de çeşitli aktörler bu hissi tetiklemektedir. Ayrışma hissini tetikleyen aktörler; esnaf/işletmeler, çalışanlar, yabancı turistler ve diğer yerli turistlerdir. Ayrışma ana temaları, tüketici temelli ve sosyokültürel olarak ikiye ayrılmaktadır. İşletmelerin hedef kitlesi olma, fiyatlandırma, kalitede bağımlılık ve hizmet alma gibi somut deneyimlere dayalı ortaya çıkan tüketici temelli temalarda çoğu yerli turist, üstünlük-aşağılık ikileminin aşağı kısmında hissetmektedir. Yabancı turistlerin tüketici olarak yerel esnaf, işletmeler ve çalışanları tarafından daha çok tercih edilmesi, daha iyi hizmet alması ve kaliteye erişmesiyle fiyat yönünden avantajlı olduğu algısı, yerli tu- ristin eksik hissetmesine ve bir komplekse girmesine neden olabilir görünmektedir. Bu kompleksin bir sonucu olduğu kesin olmamakla beraber, sosyokültürel temalardan genel davranış ve tutum açısından üstün taraf olduklarını düşünenler çoğunluktadır. Kültürel/tarihi değerler ve çevreye verilen önemle ilgili olan son iki temada ise yabancı turistler üstün görülmektedir.

Alanyazında da yabancıların esnafın ana hedef kitlesi olduğu ve ilgisine daha çok maruz kaldığ1 dillendirilmektedir (Dönmez ve Çakıcı 2013b; Üngüren vd. 2015). Destinasyonda yer alan işletme sahipleri ve esnaf, yerli turistle alışveriş yapmaktansa daha yüksek harcama kabiliyetine istinaden yabancı turistle alışveriş yapmayı tercih etmektedir (Sarı ve Bayraktar 2018). Bunun sonucunda pandemi gibi kriz dönemlerinde yabanc1 turistlerin azalmasının veya yokluğunun, yerli turistlerce olumlu karşılanmış olması normaldir.

Fiyatlandırma, yerli turistlerin hassas olduğu bir konu olarak nitelendirilmektedir (Ayaz ve Musellim 2021). Yabancı turistle aralarında fiyat ayrışması olmasını kendileri açısından adaletsiz algılamaları şaşırtıcı değildir (Dönmez ve Çakıc1 2013b). Yabancıların kurla artan ödeme kabiliyeti, yerli turistlerin Türk lirası bazındaki ödeme kabiliyetini düşürmektedir (Bozkurt ve Pekmezci 2015; Şanlığlu ve Özcan 2017). Gelgelelim kimi yerli turistler, empatiyle yaklaşarak yabancılara haksızlık yapılmaması gerektiğini söylemektedir.

Kalite belirleyiciliği açısından bakıldığında yerli turistler alacakları hizmetin yüksek veya düşük kaliteye sahip olması ihtimalinin yabancı turiste bağlı olduğunun bilincindedir. Yani aynı ortamda bulunmaları nedeniyle hizmete erişimlerinin zorlaşacağını, ödeyecekleri bedelin yükseleceğini düşünmelerine rağmen, aynı zamanda alacakları kalitenin düzeyini onlara bağlı görmekte ve karar sürecinde yabancı turistin varlı̆̆1$\mathrm{n} ı$ bir ölçüt olarak değerlendirmektedirler. $\mathrm{Bu}$ da bir çeşit yerli turist dilemması olarak ele alınabilir görünmektedir.

Hizmet alma ise yerli turistlerin ikinci plana atılma hissini ve yabancı turistin kendilerinden daha önemli olduğu düşüncesini en yoğun hissettikleri temadır. Hizmet almada yabancılara daha fazla önem verildiği düşüncesi adeta içsel-

Cilt 33 • Sayı 2 • Güz 2022 • 15 
leştirilmiş ve hizmetin kalitesi değil, hizmet alırken bu ayrıma maruz kalmamak deneyimi olumlu etkileyen bir unsur haline gelmiştir.

Hizmet alma temasında yerli turistin "suçladığ1" aktörler yerli esnaf/işletmeler ve çalışanlardır. Kimi yerli turistler ise doğrudan diğer yerli turistleri eleştirerek turistik deneyimlerinde yaşadıkları soruların kaynağı olarak dahil oldukları iç grubun davranışlarını ve beklentilerini göstermektedir. Buna göre işletmeler ve çalışanlar hem yerli hem yabancı çok sayıda turiste hizmet sunma çabasındadır ve bazı noksanlıklarla karşılaşılabilir. Buna istinaden beklentilerin daha gerçekçi inşa edilmesi gereklidir. Bu yorumları yapan turistler yaşadıkları deneyimde karşılaştıkları olumsuz yanları diğer yerli turistlere mal etmektedirler.

Alanyazın incelendiğinde yerli turistlerin yabancı turistlere karşı özellikle yaşam tarzı, kültürel normlar ve alışkanlıklar açısından olumsuz değerlendirmeleri olduğu görülmektedir (Dönmez ve Çakıcı 2013a). Bu çalışmada da genel davranış ve tutum temasında sosyal karşılaştırma paradigmasının önermelerinin geçerli olduğu anlaşılmaktadır. Yerli turistler, iç grup olan Türklerin ahlak ve görgü yönünden diş grup olan yabancı turistlere göre daha üstün olduğunu düşünmektedirler. Hatta bazı yorumlarda doğrudan milliyetle ilişkili değerlendirmeler dahi yapıldığı görülmüştür. Ancak etik kaygılar nedeniyle bu yorumlardan alıntılara yer verilmemiştir. Bu yorumlarda milliyetler arası karşılaştırmalar, hijyen/temizlik alışkanlıklarına yönelik ithamlar ve gelecekte yaşanacak bir deneyimde benzeri milliyetlerden yabancı turistten kaçınmak için başka yerlerin tercih edileceğine dair ifadeler bulunmaktadır.

İlgili temada ilk bakışta bir çeşit üstünlük kompleksi ve sosyal karşılaştırmada iç grubu olumlama sezilse de bazı yorumlarda aksine şahit olunmuştur. Yine Dönmez ve Çakıcı'nın (2013a) çalışmasında yerli turistler, yabancı turistlere yönelik nezaket ve görgü yönünden olumlu algilara sahip olarak nitelendirilmiştir. $\mathrm{Bu}$ çalışmada yazarların inceledikleri yorumlar arasında bunu doğrulayan ve hatta asıl eleştirilmesi gerekenin yerli turist olduğunu belirten ifadelerle karşılaşılmıştır. Bu durum sosyal karşılaştırma paradigmasında iç grubun daha üstün görülmesi önermesiyle çelişmektedir. İlgili ifadelerde ayrışmayı yaratanın yabancı turist, çalışan ve işletme değil, doğrudan yerli turistin istekleri ve beklentileri olduğu öne sürülmektedir. Hatta bir diğer yorumda yerli turist doğrudan sorunun kaynağ 1 olarak nitelendirilmekte ve iç grupla ilişkili bir çeşit aşağılık kompleksi sezilmektedir.

Genel davranış ve tutumların içinde yabancı turistleri daha üstün gören bu yorumlar, kültürel ve tarihi değerlere verilen önem ve çevresel duyarlılık temalarında da sürmektedir. Söz konusu grup için yabancı turistler ise hem davranış ve tutumlar hem de kültürel, tarihi ve çevresel duyarlılık açısından çok daha üstün algılanmaktadır. Diğer yerli turistlerin bu değerlere sahip ç1kacak şekilde davranması yönünde telkinler söz konusudur.

Gelecekteki araştırmalar, ortaya konan temaların derinlemesine görüşmelerle irdelenmesine ve potansiyel yerli turist kompleksi ölçeğinin geliştirilmesine odaklanabilir. Ampirik bir çalışmayla elde edilen faktörlerin veya sıklık derecelerinin ilişkilendirilmesi ve karşılaştırılması yararlı olacaktır. Ayrıca yerli turistlerin sorumlu tuttuğu aktörler üzerinden tipolojilere ayrılmasına yönelik bir araştırma gerçekleştirilmesi faydalı olacaktır. Son olarak yerli turistlerin, yabancı turist olarak başka ülkelere gitmeleri durumunda, Türkiye'deki gibi bir ayrışmayla karşılaşılıp karşılaşılmadığı sorgulanabilir.

Sektörel açıdan ise özellikle yorumların konusu olan Türkiye' nin güney kıyı bölgelerinde yerli turistlere karşı tavır değişikliğine gidilmesi gerektiği aşikardır. Turizmin sürdürülebilirliği için yerli turistlerde gelişen sözde bir kompleksin oluşumu tehdit unsuru olabilmektedir. Normal dönemlerde turizm paydaşlarının yerli turisti soktuğu kompleks nedeniyle, pandemi benzeri kriz dönemlerinde öç alma duygusuyla hareket etmek, turistik faaliyetlere katılmakta isteksiz olmak veya katıldığında daha yüksek pazarlık gücüne sahip olunması nedeniyle işletmeyi zorlamak gibi tutumlar ortaya çıkabilir. Esnaf/işletmeler ve çalışanların ayrışma hissini tetikleyen en etkili aktörler olduğu göz önüne alındığında 
bu çalışma, sektörel farkındalık yaratılması açısından kritik bir katkı sağlamaktadır. Bundan kaçınmak adına verilebilecek önemli bir öneri yerli turistlerin dönemsel değil, sürekli müşteri olarak değerlendirilmesi ve özellikle çalışanların bu doğrultuda yönlendirilmesidir. Öte yandan paydaşların yerli turistlerin ayrışma hissedip hissetmediklerini ve hissediyorlarsa düzeylerini anlaması, destinasyon yönetimi açısından yol gösterici olacaktır. İşletmecilerin yabancı ve yerli turistlere karşı davranış farklılı̆̆ının olup olmadığ gizli müşteri uygulamalarıyla açığa çıkarılırsa, çeşitli yaptırımlar eşliğinde sorunlar çözülebilir. Aynı uygulamayla yabancıların az olduğu dönemlerde hizmet, kalite ve fiyat gibi faktörlerdeki değişiklikler tespit edilip önüne geçilmesi için adımlar atılabilir.

Çalışmanın en önemli sınırlılığı, ampirik veriden mahrum olmasıdır. Kaçınmaya özen gösterilse de nitel araştırmanın doğasından ötürü değerlendirmelere araştırmacıların ön yargıları yansımış olabilir. Ayrıca, verilerin spesifik bir destinasyon özelinde toplanmamış olması ve online yorumlarla kısıtlı olması yapılan çıkarımların tutarlılı̆̆ını düşürebilir.

\section{KAYNAKÇA}

Allen, G. N., Burk, D. L. ve Davis, G. B. (2006). Academic Data Collection in Electronic Environments: Defining Acceptable Use of Internet Resources, MIS Quarterly, 30 (3): 599-610.

Altun, E. ve Çınar, K. (2019). İnanç Turizmi Kapsamında Mevlânâ Müzesi'ni Ziyaret Eden Turistlerin Seyahat Motivasyonları Üzerine Bir Araştırma, Necmettin Erbakan Üniversitesi Siyasal Bilgiler Fakültesi Dergisi, 1 (1): 14-42.

Ayaz, N. ve Musellim, F. (2021). Yerli Turistlerin Fiyat Alg1s1 Üzerine Bir Araştırma, Journal of Humanities and Tourism Research, 11 (2): 396-407.

Bayram, S. (2018). Psikanalitik Bir Okuma: Murtaza, Akademik Sosyal Araştırmalar Dergisi, 6 (83): 192-201.

Bozkurt, K. ve Pekmezci, A. (2015). Turizm Talebi ve Döviz Kuru Şokları: Türk Turizm Sektörü İçin Ekonometrik Bir Analiz, Eskişehir Osmangazi Üniversitesi İIBF Dergisi, 10 (2): 91-105.

Coşan, B. (2021). Yerli Turisti Unutmayın. Hürriyet, https:// www.hurriyet.com.tr/ekonomi/yerli-turisti-unutmayin-41943876, Erişim tarihi: 06.12.2021.

Çakar, K. (2018). Critical Success Factors for Tourist Destination Governance in Times of Crisis: A Case Study of Antalya, Turkey, Journal of Travel $\mathcal{E}$ Tourism Marketing, 35 (8): 786-802.
Dönmez, B. ve Çakıcı, A. C. (2013a). Turist - Turist Etkileşimi: Yerli Turistlerin İngiliz Turistlere Bakış Açıları Üzerine Keşifsel Bir Araştırma, Düzce Üniversitesi Sosyal Bilimler Enstitüsü Dergisi, 3 (1): 37-61.

Dönmez, B. ve Çakıc1, A. C. (2013b). Turist - Turizmci Etkileşimi: Yerli Turistlerin Turizm İşletmecilerine ve Çalışanlarına Bakış Açıları Üzerine Keşifsel Bir Araştırma, Çă̆ University Journal of Social Sciences, 10 (2): 137-150.

Güzel, Ö. (2011). Türkiye'de İç Turizm Pazarı Analizi ve Pazarı Canlandırmaya Yönelik Alternatif Turizm Olanakları, Mustafa Kemal Üniversitesi Sosyal Bilimler Enstitüsü Dergisi, 8 (16): 127-144.

Kılıçaslan, A. ve Aydınözü, D. (2000). Afyon İlinde Kaplıca Turizmi ve Özellikleri, Türk Coğrafya Dergisi, (35): 347-359.

Kınacı, B., Albuz Pehlivan, N. ve Seyhan, G. (2011). Turizm ve Çevre (Çevre Koruma). Ankara: PEGEM.

Kızıldemir, Ö. ve Sarışık, M. (2018). Turist Harcamalarının Bölgesel Kalkınmaya Ekonomik Etkileri: Adana Örneği, Journal of Tourism and Gastronomy Studies, 6 (2):128-142.

Knapen, J. E., Blaker, N. M. ve Vugt, M. V. (2018). The Napoleon Complex: When Shorter Men Take More, Psychological Science, 29 (7): 1134-1144.

Kozinets, R. V. (2010). Netnography: Doing Ethnographic Research Online. Londra: SAGE.

Köşker, H. (2017). Krizlerin Turizm Sektörüne Etkileri Üzerine Bir Araştırma: 2016 Yılı Türkiye Örneği, Akademik Bakış Dergisi, Temmuz-Ağustos (62): 216-230.

Kuşluvan, Z. (2002). Türkiye'de İç Turizm Talebinin Analizi, Journal of Travel And Tourism Research, 2: 1-21.

Kültür ve Turizm Bakanlığı. (2021). Turizm İstatistikleri. Ankara:Kültür ve Turizm Bakanlığ1, https://yigm.ktb. gov.tr/TR-9851/turizm-istatistikleri.html, Erişim tarihi: 25 Eylül 2021.

Merriam, S. B. (2015). Nitel Araştırma: Desen ve Uygulama İçin Bir Rehber. Çev. Ed. Selahattin Turan). Ankara: Nobel Yayın Dağıtım.

Sarı, C. ve Bayraktar, S. E. (2018). Kemer İlçesindeki Esnafın Turizm ve Turist ile İlgili Tutumları, 30. Yıl Uluslararası Coğrafya Sempozyumu (ss. 167-187). Ankara: TÜCAUM.

Seckelmann, A. (2002). Domestic Tourism - A Chance for Regional Development in Turkey?, Tourism Management, 23 (1): 85-92.

Selvi, K. (2018). Narsisistik Kişilik Bozukluğunun, Adler'in Aşağılık ve Üstünlük Kompleksleri Açısından Analizi: Bir Olgu Çalışması, AYNA Klinik Psikoloji Dergisi, 5 (1): $1-20$.

Soylu, A., Özdipçiner, N. S. ve Ceylan, S. (2018). Yerli ve Yabanc1 Turistlerin Destinasyon İmajına İlişkin Alg1 Farklılıkları: Pamukkale Örneği, Hitit Üniversitesi Sosyal Bilimler Enstitüsü Dergisi, 11 (3): 2481-2493.

Şahin, S., Tezcan, A. E. ve Bekci, M. (2018). Yerli Turistlerin Türkiye, İstanbul, Turizm ve Turist Rehberi ile İlgili Metaforlar1, Turizm Akademik Dergisi, 5 (1): 251-264.

Şanlığlu, Ö. ve Özcan, E. Ö. (2017). Türkiye'de Uygulanan Turizm Teşvik Politikaları ve Sonuçları Üzerine Bir Değerlendirme, Kırıkkale Üniversitesi Sosyal Bilimler Dergisi, 7 (2): 97-118. 
Tang, Z. (2015). An Integrated Approach to Evaluating The Coupling Coordination between Tourism and The Environment, Tourism Management, 46: 11-19.

Trepte, S. ve Loy, L. S. (2017). Social Identity Theory and SelfCategorization Theory. İçinde P. Rössler, C. A. Hoffner ve L. van Zoonen (Düzenleyenler), The International Encyclopedia of Media Effects (ss. 1-13). Chichester, West Sussex; Malden, MA: John Wiley \& Sons.

TripAdvisor (2021). TripAdvisor Web Sitesi Şartları, Koşullar1 ve Bildirimleri, https://tripadvisor.mediaroom.com/TRterms-of-use, Erişim tarihi: 11.12.2021.
Turner, J. C. (1975). Social Comparison and Social İdentity: Some Prospects for Intergroup Behaviour, European Journal of Social Psychology, 5 (1): 5-34.

Üngüren, E., Arslan, S. ve Kaçmaz, Y. Y. (2015). Bir Turist Taciz Türü Olarak Hanutçuluğun Turistler Üzerindeki Etkisi, Akdeniz İ.I.B.F. Dergisi, 32: 129-174.

Yenişehirlioğlu, E. ve Salha, H. (2020). Covid 19 Pandemisinin Türkiye İç Turizmine Yansımaları: Değişen Talep Üzerine Bir Araştırma, İstanbul Ticaret Üniversitesi Sosyal Bilimler Dergisi, Bahar (Covid19-Özel Ek): 355-368.

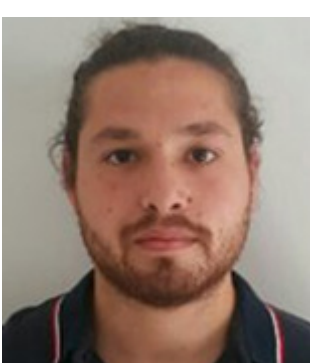

\section{Gürkan AYBEK}

Akdeniz Üniversitesi Turizm Fakültesi Gastronomi ve Mutfak Sanatları bölümünden mezun oldu (2017). Yüksek lisans derecesini Akdeniz Üniversitesi Gastronomi ve Mutfak Sanatları Ana Bilim Dalı'ndan aldı (2020). Doktora derecesi için Akdeniz Üniversitesi Gastronomi ve Mutfak Sanatları Ana Bilim Dalı'nda eğitimine devam etmektedir. Akdeniz Üniversitesi'nde çalışmaya başlamıştır (2019) ve halen aynı yerde görev yapmaktadır. Temel çaıışma alanları, gastronomi, yiyecek içecek işletmeciliği ve turizmdir.

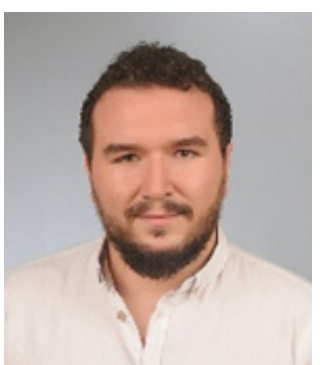

\section{Altan DEMIREL}

Anadolu Üniversitesi Turizm İşletmeciliği ve Otelcilik Yüksekokulu'ndan mezun oldu (2013). Yüksek lisans derecesini Akdeniz Üniversitesi'nden Turizm Işletmeciliği Dalı'ndan aldı (2017). Doktora eğitimine Akdeniz Üniversitesi Turizm işlemeciliği Dalı'nda başladı (2017). Antalya Akev Üniversitesi'nde çalışmaya başladı (2020). Halen Antalya Akev Üniversitesi Meslek Yüksekokulu Seyahat-Turizm ve Eğlence Hizmetleri, Turist Rehberliği Programında öğretim görevlisi olarak görev yapmaktadır. Temel çalışma alanları, turizm işletmeciliği, kültürel miras ve dijitalleşmedir.

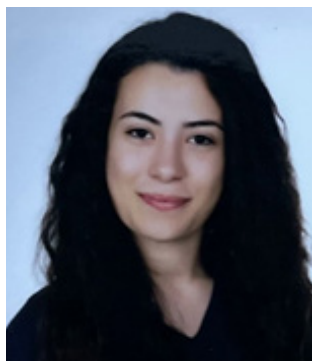

\section{Cansu Ece ÖNER}

Akdeniz Üniversitesi Turizm Fakültesi Turizm İşletmeciliği (\%100 İngilizce) Bölümü’nden mezun oldu (2019). Yüksek lisans derecesi için Akdeniz Üniversitesi Turizm İşletmeciliği Anabilim Dalı'nda eğitimine devam etmektedir. Temel çalışma alanı, turizmdir. 